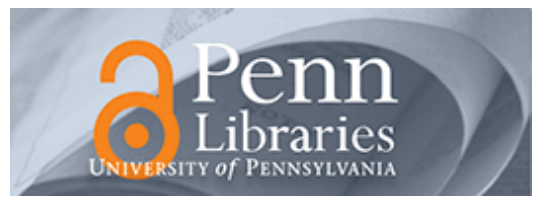

University of Pennsylvania

ScholarlyCommons

Management Papers

Wharton Faculty Research

$7-2013$

\title{
A Study of the Extent and Potential Causes of Alternative Employment Arrangements
}

Peter Cappelli

University of Pennsylvania

JR Keller

University of Pennsylvania

Follow this and additional works at: https://repository.upenn.edu/mgmt_papers

Part of the Business Administration, Management, and Operations Commons, and the Economics Commons

Recommended Citation

Cappelli, P., \& Keller, J. (2013). A Study of the Extent and Potential Causes of Alternative Employment Arrangements. ILR Review, 66 (4), 874-901. http://dx.doi.org/10.1177/001979391306600406

This paper is posted at ScholarlyCommons. https://repository.upenn.edu/mgmt_papers/81

For more information, please contact repository@pobox.upenn.edu. 


\title{
A Study of the Extent and Potential Causes of Alternative Employment Arrangements
}

\author{
Abstract \\ The notion of regular, full-time employment as one of the defining features of the U.S. economy has been \\ called into question in recent years by the apparent growth of alternative or "nonstandard" work \\ arrangements-part-time hours, temporary help, independent contracting, and other configurations. \\ Identifying the extent of these arrangements, whether they are increasing and where they occur, is the first \\ step to understanding their implications for the economy and the society. But such steps have been \\ difficult to take because of the lack of appropriate data. Based on a national probability sample of U.S. \\ establishments, the authors present estimates of the extent of these practices, evidence on changes in \\ their use over time, and analyses that contribute to understanding why alternatives have come into play.

\section{Disciplines} \\ Business Administration, Management, and Operations | Economics
}


NBER WORKING PAPER SERIES

A STUDY OF THE EXTENT AND POTENTIAL CAUSES OF ALTERNATIVE EMPLOYMENT ARRANGEMENTS

\author{
Peter Cappelli \\ JR Keller
}

Working Paper 18376

http://www.nber.org/papers/w18376

\author{
NATIONAL BUREAU OF ECONOMIC RESEARCH \\ 1050 Massachusetts Avenue \\ Cambridge, MA 02138 \\ September 2012
}

The views expressed herein are those of the authors and do not necessarily reflect the views of the National Bureau of Economic Research. Support from the Russell Sage Foundation is gratefully acknowledged.

NBER working papers are circulated for discussion and comment purposes. They have not been peerreviewed or been subject to the review by the NBER Board of Directors that accompanies official NBER publications.

(C) 2012 by Peter Cappelli and JR Keller. All rights reserved. Short sections of text, not to exceed two paragraphs, may be quoted without explicit permission provided that full credit, including $(\mathrm{C}$ notice, is given to the source. 
A Study of the Extent and Potential Causes of Alternative Employment Arrangements

Peter Cappelli and JR Keller

NBER Working Paper No. 18376

September 2012

JEL No. J2,J21,J41,M12,M51,M54,M55

\begin{abstract}
The notion of regular, full-time employment as one of the defining features of the U.S. economy has been called into question in recent years by the apparent growth of alternative or "nonstandard" arrangements - part-time work, temporary help, independent contracting, and other arrangements. Identifying the extent of these arrangements, whether they are increasing, and where they occur is the first step for understanding their implications for the economy and the society. But this has been difficult to do because of the lack of appropriate data. We present estimates of the extent of these practices based on a national probability sample of U.S. establishments, evidence on changes in their use over time, and analyses that help us begin to understand why they are used.
\end{abstract}

\author{
Peter Cappelli \\ The Wharton School \\ Center for Human Resources \\ University of Pennsylvania \\ Philadelphia, PA 19104-6358 \\ and NBER \\ cappelli@wharton.upenn.edu \\ JR Keller \\ University of Pennsylvania \\ 2000 Steinberg Hall-Dietrich Hall \\ 3620 Locust Walk \\ Philadelphia, PA 19104-6370 \\ jkel@wharton.upenn.edu
}




\section{Introduction}

It is common to refer to all individuals who are working on behalf of an organization as employees, yet organizations increasingly use an array of alternative arrangements other than employment for engaging workers. Alternatives to employment relationships include temporary help, leased employees, independent contracting, and using Professional Employer Organizations (PEO's). Part-time work, though a type of employment, is often included in the set of alternative arrangements because employers typically treat workers in those roles differently (e.g., no benefits or career advancement prospects). Despite their importance in the economy, we know surprisingly little about how extensively these alternative arrangements are used.

Part of the challenge in identifying their use has been the difficulty in agreeing on the common elements of these alternative arrangements (Cappelli and Keller 2013). The phrase "nonstandard work," for example, is all-inclusive, but ignores the considerable variation in the attributes of the different components within that classification. The term "contingent work" is also common and refers to the sense that the relationships on average are less secure and more contingent on short-term changes in employer demand than is regular employment. Yet some of these alternative arrangements can be reasonably regular and stable, especially part-time jobs, and some full-time, regular jobs can nevertheless be quite insecure. As a result, it is perhaps best to examine each of the specific alternative arrangements and see how extensively they are used.

We examine these alternative arrangements using national probability data from the Census. The 2000/2001 National Employer Survey is the largest and most recent nationally representative establishment-level survey on alternative work arrangements, and it contains detailed information of employment in alternative work arrangements as a fraction of direct-hire employees, data which is not found in any other source. And unlike previous establishment-level 
surveys, multiple versions of the NES have been conducted over time, providing an opportunity to examine trends in their use.

The descriptive data from the survey allows us to address three quite important questions. The first is simply, how extensive are each of these alternative arrangements? Second, how has the incidence of their use changed over time? Finally, what can we add to what little is known about why employers choose different arrangements? While the results below are best seen as descriptive and preliminary, given the relevance of the topic and the difficulty in accessing these data again, it seems appropriate to present what is available.

Overall we find that these alternative arrangements are used extensively, but there is considerable variation in the use of each of the different arrangements. Their use is highly concentrated among relatively few establishments who use them very intensively, suggesting that establishment-level factors must be involved in understanding that variance. The data over time suggests an overall increase but, again, the growth varies considerably across arrangements. Finally, we present preliminary analyses examining prior hypotheses about the establishmentlevel attributes likely to be associated with greater use of these alternative arrangements. We find relatively little support for the notion that their use is driven by either cost savings or flexibility needs, but some support for the idea that they vary with the ease of monitoring tasks and job performance.

\section{Interest in alternative arrangements}

What we now think of as the traditional employment relationship in the Anglo-U.S. context evolved from the traditions of agrarian economies in England, where employment relationships were based on crop cycles. Unless otherwise stated, hired help on farms was engaged for one year, following the cycle of crops from planting to harvest, to prevent farmers 
from hiring laborers from Spring through Harvest and then laying them off in the Winter when there was nothing much for them to do but, as a consequence, nothing much to eat. This arrangement was canonized into common law and carried over to the U.S. and commonwealth countries. On the European continent, similar arrangements were put in place through legislation (Feinman 1976).

The "at will" employment model in the U.S. developed later in a context where labor was scarcer than in England. The notion that employees and employers could walk away from employment arrangements at any time - the "at will" idea - was a sharp departure from earlier arrangements (Miles 2000). The rise of industrial employment in the early 1900s created opportunity to apply the "at will" model on a large scale and led to arrangements where a reasonably stable group of skilled workers was surrounded by an ever-changing casual workforce. While turnover rates of 300 percent or more were common in U.S. industry through the 1920s, the rise of capital-intensive, mass production arrangements created the need for many more semi-skilled workers and, in turn, a need for greater stability in the workforce. The notion of stable, full-time jobs for average workers that could last a lifetime began relatively late, after the Depression, and was enforced by collective bargaining agreements in union facilities and similar arrangements (seniority-based provisions, etc.) in non-union firms. That model of "standard" employment became the basis for modern employment law in The New Deal, for assumptions about labor markets and the economy that governed policy, and for much of civil society ${ }^{1}$.

The experiences of the 1980s represented a sharp rift in that model of standard employment as downsizing waves eroded what had been lifetime jobs. Initially, temporary help

\footnotetext{
1 The historical background to nonstandard work can be found in Cappelli (2000), and the more recent context is
} outlined in Cappelli (1999), Chapters 2 and 3. 
engaged through agencies provided a means for lowering labor costs in this period and was followed by a steady rise in the variety of alternative arrangements, supported by the efforts of the temp industry to legitimize these alternatives as acceptable practices (Smith and Neuwirth 2008). These other practices included contract or leased employees, similar to temporary help except that the relationships are often long-term; independent contracting where relationships can be short-term like temps but lack an intermediary between worker and employer; engaging temp workers directly without an agency intermediary ("direct-hire" temps); Professional Employer Organizations (PEOs) that become the legal employer while leaving the day-to-day management of workers to the client's supervisors (see, e.g., Cappelli 1999); vendor-on-premise services where workers are employees of the vendor but can be attached permanently to the client's location (see Theodore and Peck 2002).

There are several reasons for both practical and theoretical interest in these arrangements, the first being that they appear to be both widespread and growing. Lou, Mann and Holden (2010) report, for example, that temporary agency workers doubled as a percentage of the total US workforce from 1990 through 2000, accounting for 10 percent of all employment growth during this period. The number of workers in PEO arrangements has risen even faster, albeit starting at a very low base, with Lombardi and Ono (2008) reporting a 386 percent growth between 1992 and 2002. Many of these arrangements reduce the fixed costs of having workers engaged in tasks for the organization, allowing organizations to adjust the amount of work and the pay while making it easier to end the relationship ${ }^{2}$.

A large subset of these arrangements pushes work outside of the usual definition of the boundary of the firm, separating the legal employment relationship from the day-to-day

\footnotetext{
${ }^{2}$ Part-time workers may be the exception here. While they do create the opportunity for more flexible staffing arrangements, the fixed costs of recruiting and hiring new workers may be similar for full- and part-time positions.
} 
management of employees (Muhl 2002; Stone 2006). Such arrangements typically introduce a third party into the relationship, raising new issues about how workers are managed and the extent to which the different parties involved are able to exercise control over the work process.

In general, alternative arrangements give a greater role to the market in shaping the terms and conditions under which work is performed. Together, they represent a dramatic shift from traditional employment.

Data on the use of specific arrangements is especially important given the recent interest in understanding the issues raised in situations where employers use multiple alternative arrangements. For example, how is the choice among temps, contractors, and full-time workers determined (Kalleberg et al. 2003)? What are the challenges for mangers who have different workers engaged on their behalf under very different arrangements (Smith 2001)? How do the workers operating under these different arrangements interact with each other (Davis-Blake and Broschak 2003)? All of these issues become more important as these alternative arrangements become more widespread.

\section{Measuring the extent of nonstandard employment}

Efforts to collect data on these alternative arrangements have largely relied on individuallevel data surveys, especially the Contingent Work Supplement (CWS) to the Current Population Survey (CPS) conducted by the Bureau of Labor Statistics (BLS). While studies using these data have done much to further our understanding of alternative arrangements and their effects on workers, they are of necessity limited in the picture they can present of the prevalence of such arrangements in the U.S. economy.

The BLS has been particularly interested in contingent work, which it defines as "any job in which an individual does not have an explicit or implicit contract for long-term employment" 
(Polivka 1996). The key criterion in the definition of contingent work, therefore, is the employee's perception of the stability of their job ${ }^{3}$ and not the actual nature of the relationship. By 2005, 4.1 percent of the workforce were in arrangements that workers perceived as contingent, almost identical to the 4.0 percent reported in 2001 and slightly lower than the estimates from previous surveys in 1999 (4.3 percent) and 1997 (4.9 percent) (von Hippel et al. 2006). The stability of these figures despite business cycle variations and other changes leads to the question as to whether perceptions of instability and insecurity may self-adjust.

Another concern about individual-level data is whether individual workers are able and willing to identify the type of arrangement they are in. Other researchers have noted that if the many respondents who were unable to answer whether their work was contingent were included in the BLS measure, the percentage of contingent workers would be nearly 10 percent or almost two and a half times the current estimate of 4.1 percent (Gleason 2006: 4; Belman and Golden 2000). Dey and colleagues (2006) similarly observe that despite the addition of clarifying questions, difficulties with reporting accuracy remain (Dey, Houseman, and Polvika 2006). Contingent work does not map neatly onto categories of non-standard work. For example, a 1999 BLS survey reports that only 10 percent of part-time workers say that their jobs are contingent (Hipple 2001).

The most important limitation to the CPS data on individuals is that asking a worker about the nature of their working arrangements does not tell us how often or even if they are working at all. For example, individuals may correctly identify themselves as independent contractors even if they have no work, similar to temp agency workers who have no

\footnotetext{
3 "Any job in which an individual does not have an explicit or implicit contract for long-term employment" (Hipple 2001)
} 
assignments ${ }^{4}$. Social desirability biases may also affect how individuals respond (e.g., consultant/independent contractor sounds better than temp). Finally, most attempts to measure the use of alternative arrangements with individual-level data have not used the full range of intermediaries or arrangements, such as engagement through Professional Employer Organizations.

An alternative approach to mapping the extent to which nonstandard arrangements are being used is to ask employers directly about their use. The most obvious advantage to this approach is that the responses tell us about the actual use and extent of these arrangements in the workplace. Employer respondents may not have data on the number of individuals working under each arrangement at their fingertips (sometimes true even for the number of direct employees), but they are likely to be well aware of the different alternative arrangements, as each has implications for their budgets and for compliance with both tax and employment law.

Data from employers has been examined in the past by other researchers relying on a variety of survey instruments. Abraham (1990) used a survey from the Bureau of National Affairs, Houseman (2001) used data from the 1995 W.E. Upjohn survey of 550 establishments, and Kalleberg and colleagues $(1995,2003)$ surveyed HR managers at 1,002 establishments as part of the 1996 National Organizations Survey (NOSII, see Kalleberg et al. 1995 for details). Abraham and Taylor (1996) examine the related question of the propensity of establishments to contract out certain business services, such as janitorial and accounting services, with a supplement to the Industry Wage Survey conducted by the BLS.

\footnotetext{
${ }^{4}$ The Bureau of Labor Statistics attempted to measure how many individuals worked for vendors/contractors by asking whether they performed their work for an organization other than their employer and did so solely for that other organization for a period up to a year. That definition would seem to capture many individuals who work as contractors, but it might also exclude others, for example, who work in one place for more than a year or performed work for two organizations, as the cutoffs are reasonably arbitrary. See http://www.bls.gov/news.release/conemp.nrO.htm for details of the CPS survey.
} 
Houseman (2001) found that in addition to part-time help, 78 percent of employers used at least one other alternative arrangement (agency temps, on-call workers, independent contractors and workers from contractors), slightly higher than the 70 percent reported by Kalleberg et al. (2003) using the NOSII data. It is somewhat more difficult, however, to estimate the use of each arrangement in any simple way given the response options in these surveys, which were categorical. The design of the most recent NES survey extends these prior approaches in important ways.

\section{The National Employer Surveys (NES I, NES II \& NES III)}

The National Employer Survey is an establishment-based survey conducted by the Census Bureau. It was first conducted in 1994 (NES I) with a second major version in 1997 (NES II). The third version of the NES, the focus of this study, began in late 2000 and was completed in early 2001. (For convenience we refer to it as the 2000 survey, or NES III). All three were sponsored by the National Center on the Educational Quality of the Workforce (EQW). The NES III was motivated by concerns about the corporate restructuring of the 1990s, and employer practices more generally. Among those new concerns was an interest in identifying the extent of nonstandard work in the U.S. economy. These data are not publicly available and have not been used to examine workplace issues before ${ }^{5}$.

The NES I sample was drawn from the Standard Statistical Establishment List (SSEL), a listing of establishments drawn from Internal Revenue Service records and based on mandatory tax reporting by employers. As such, it is the definitive list of employers and should be superior

\footnotetext{
${ }^{5}$ Access to the data has been on delayed for much of the period since it was collected and on indefinite hold since 2009 pending resolution of issues between the Census, which administered the survey, and the Internal Revenue Service, which "owns" the sampling frame. The challenge for researchers is that this means that all requests to, 1) access the data, 2) have the analyses approved, and 3) approve any publications, must be vetted by two agencies that disagree over who owns the data. In short, issues out of any researcher's control have prevented this data from being used despite its being developed, in large measure, in response to social science researchers' argument that the absence of a representative survey data about organizations represented a serious gap in our knowledge about the economy and society.
} 
in its representativeness to other commonly used employer sampling frames (see, e.g., Kalleberg et al. 1990). The sampling frame is limited to private sector establishments with more than 20 employees that are not uniquely a headquarters. Sampling establishments leads to more precise responses than sampling firms as firm-level data, especially in larger firms, represents averages across establishments where practices may be quite different. The decision to exclude small establishments was made because they are less likely to have formal programs and practices, which were the focus of the survey, and they also account for a relatively small percentage of the workforce. A 72 percent response rate yielded 3,173 usable responses.

The NES II sampling frame was also drawn from the SSEL using identical criteria, with a 78 percent response rate yielding 3,463 usable responses. The sampling frame included a subset of the establishments that completed the NES I. Seventy-five percent of those establishments which were resurveyed responded, creating a longitudinal panel of 915 establishments surveyed in both 1994 and 1997.

The sampling frame for the NES III was drawn from the establishments that also responded the NES II, some of which also responded to the NES I, with an 85 percent response rate yielding usable responses from 2,825 establishments. The NES III survey responses thus created two additional longitudinal panels: 814 establishments who responded to all 3 NES surveys (1994, 1997, 2000), and 2,011 establishments surveyed in both 1997 and 2000. The longitudinal aspects of the survey make it easier to examine changes over time in practices, especially in the same establishments, albeit at the expense of representativeness of the sample at each point in time. The survey was conducted between December 2000 and January 2001, with questions referring to the 2000 calendar year. Because of the sampling decisions in the prior surveys, it oversamples manufacturing establishments. As we note below, however, the 
estimates we present from each of the surveys are weighted to make them more representative of private sector establishments with more than 20 employees.

The survey was administered by the Bureau of the Census as a telephone survey using computer-assisted telephone interviewing (CATI), allowing the interviewer to clarify any questions about meaning of different arrangements or what data was being requested. Several questions asked about the number of workers engaged through the broad range of alternative arrangements, as opposed to categorical responses, enabling more precise estimates. A caveat is that the questions asked in the three surveys have not been entirely consistent in their wording over time, an issue we address below. Some types of nonstandard work emerged after the initial surveys were conducted, such as Professional Employer Organizations, and questions about others were not asked in earlier surveys. Nevertheless, the NES III data are the most recent available for examining alternative arrangements in the U.S. workplace and while other surveys have asked about individual arrangements, none to our knowledge have examined the set we consider here. Finally, the longitudinal aspects of the survey design provide a unique opportunity to examine trends in nonstandard work over time.

\section{Descriptive Results for Nonstandard Arrangements}

Table 2 presents mean responses from the establishments surveyed in the 2000 NES.

These estimates are weighted by the proportion of total employment in the private sector workforce associated with each industry to make them more representative of the population of all workers in the private sector workforce. There are other choices for weighting results like these (e.g., by establishment size) that might yield different results, but weighting by industry seemed particularly important here given that the sample over-represented manufacturing-related industries. 
The first column indicates the percentage of all establishments that report using a given arrangement, irrespective of the level of use. The second and third columns report the extent of use as a percentage of the total workforce - first as a percentage of regular "employees" of the establishment (including full-time, part-time, and direct hire temporary workers) and second as a percentage of total workers at the establishment, which includes those individuals who are not direct employees of the establishment but are nevertheless working at that establishment (including workers employed by agencies, PEOs and vendors on premise). ${ }^{6}$

\section{\{\{Place Table 2 about here $\}\}$}

This cross-sectional view of the pattern of use is broadly consistent with, but not identical to previous survey results. "Agency temp" arrangements have arguably been the focus of much of the prior research. Prior employee surveys found that they accounted for roughly 2 percent of the workforce (Lou et al. 2000; Autor 2003; von Hippel et al. 2006). That is the case here as well, where the average establishment has the equivalent of 2.1 percent of its on-site workers in the form of agency temps. As other studies have also found, the number of temps engaged directly by the employer, as opposed to through an agency intermediary, is even greater than the use of agency temps, 2.8 percent of on-site workers in these data. The total temporary workforce at the average establishment, therefore, is just under 5 percent of the total workforce.

Approximately 43 percent of all establishments report using at least one temp agency worker, which is significantly greater than the 29 percent reported by Kalleberg et al. (2003) but quite similar to the 46 percent reported by Houseman's (2001) survey. Interestingly, the NES III

\footnotetext{
${ }^{6}$ What the survey cannot capture is work that is being performed for the establishment but being conducted elsewhere. Such work could be embodied in components purchased from a supply chain or in tasks that are contracted out. These areas would typically be seen as outside the boundary of the firm and not alternative arrangements for managing tasks within the firm. They are conceptually quite difficult to capture, requiring, e.g., working backward from estimates of value added to track where all the value came from.
} 
shows that only 23 percent of establishments use direct hire temps, slightly less than the 30 percent reported in the NOSII (Kalleberg et al. 2003) and significantly less than the 40 percent reported in the 1995 Upjohn survey (Houseman 2001). The Upjohn survey, however, was based on firms, which are larger than establishments and therefore more likely to use direct hire temps somewhere in their operations.

Whereas worker surveys have routinely estimated the percentage of independent contractors at greater than 6 percent of the overall workforce (Hipple 2001; von Hippel 2006), the NES III data indicate that independent contractors actually at work in a representative week comprise less than 1.5 percent of the average organization's on-site workforce. Taken together, these two sets of findings suggest that there are many people calling themselves independent contractors who may not be engaged very often or for very long by clients.

Workers provided by on-site vendors excludes vendors who are doing work that could not be performed by regular employees, such as a repairman called in to service leased equipment, and asks only about vendors who are working on the premises every week. To our knowledge, these are the first systematic data available on the extent of on-site vendor use, and they show the surprising finding that while they represent less than 1 percent of on-site workers, almost 40 percent all establishments use such arrangements.

Approximately 21 percent of establishments use PEO arrangements, though workers in such arrangements account for less than 1 percent of all on-site workers, similar to the figures reported by others (Lombardi and Ono 2008; von Hippel et al. 2006; Hipple 2001). It is difficult to compare these values to those reported in the Upjohn and NOSII studies, as workers in PEO arrangements are included in broader measures of "contract" workers in those surveys. As in 
other surveys, part-time workers constitute by far the largest share of nonstandard work - just under 16 percent of all employees here.

\section{Temporary Agency Work in Detail}

The survey asks several additional questions about the use of agency temporary help, and these results are reported in Table 3. First, the survey reports the "peak use" of temps and finds that the average employer used agency temps equivalent to 3.7 percent of the workforce in their peak week over the course of the previous year. Among those who use temps at all, however, the figure is much greater, 8.7 percent. By comparison, only 8 percent of employers in the earlier Upjohn survey reported that temp agency workers exceed even 5 percent of their total workforce (Houseman 2001). The difference in these estimates may reflect the rapid growth of the temp agency industry during the latter half of 1990s (Lou et al. 2010; Peck and Theodore 2007) and suggests a larger role for temp agencies than previously thought.

\section{$\{\{$ Place Table 3 about here $\}\}$}

Second, the survey also reports in which jobs agency temps are used. The stereotype of the temp worker is an office employee, and, indeed, 41 percent of all agency temp workers are used in office jobs. But even more of them - almost 44 percent - are used in production-related jobs. Though not all establishments have production-like jobs, there are more workers overall in such jobs in the economy than in office jobs. This result, therefore, does not imply that the percentage of workers who are agency temps is greater in production jobs than in office jobs, but it does suggest that more agency temps are doing what could be thought of as "core" jobs in their establishments. Our results are consistent with recent findings indicating that even though white collar jobs are well represented in the list of growing occupations for temp agency workers (Lou 
et al. 2010), the rise in such work has been accompanied by a similar or greater rise in blue collar temp work (Dey et al. 2006).

Perhaps the most interesting statistic in the study concerns the percentage of workers who are hired by the establishment into regular employment from the pool of agency temps working in that establishment. Over 90 percent of establishments have converted temp agency workers to permanent employees. In fact, converted temp workers constitute 1.7 percent of the average establishment's on-site workforce. That may not seem like a huge number compared to the remaining 98 percent of the workforce, but it does seem significant when one compares it to the fact that agency temps represent only 2.1 percent of all workers in the average establishment. Hiring may be a very important part of what temp agencies do for their clients. ${ }^{7}$

\section{Overall Use of Alternative Arrangements}

We can also use the above data to summarize the use of alternative work arrangements according to commonly used classifications. For example, all of the above categories collectively are at least conceptually close to the definition of nonstandard work (assuming our categories exhaust contemporary instances of non-employment), and they account for 23.43 percent of all workers across all establishments. On peak days, including peak agency temp use, the figure rises to 24.96 percent across all establishments and 30.04 percent in establishments that regularly use agency temp workers.

Because part-time work is often regular and reasonably long-term, we remove it to generate a measure of the insecure or contingent component of non-standard work. This yields an overall level of 8 percent of workers across all establishments in insecure jobs, rising in peak

\footnotetext{
${ }^{7}$ Autor and Houseman (2006) examine hiring from temp agencies into regular employment by client firms for disadvantaged workers as a route out of poverty.
} 
weeks to 9.7 percent across all establishments, and 14.5 percent in establishments that regularly use agency temps.

Off-roll workers are those workers who are doing work for an establishment but are not employed by that establishment. The employer is physically separated from the location where the employees work, and the day-to-day supervisor directing their work is not necessarily their employer. ${ }^{8}$ Off-roll is equivalent to non-standard work minus part-time and direct-hire temps. Off-roll workers account for 5.4 percent of workers across all establishments, rising in peak weeks to 7.1 percent across all establishments and 11.8 percent in establishments that regularly use agency temp workers.

Average use is only one aspect of the extent to which these arrangements operate in the workplace. Additional information about the distribution of use for each employment category across establishments provides us with more detail. Table 4 presents information on that distribution, and the results are striking. The median use of all arrangements other than part-time work is zero. Even the median use of part-time work is extremely low, at 3.7 percent. In all cases, the median use is well below the mean use. In fact, the majority of establishments appear not to use nonstandard work at all, and few use even low levels of nonstandard work. Instead, a small group of establishments seems to make very extensive use of these alternative arrangements. The top 10 percent of establishments (by use of each arrangement) have a majority of their workforce in the part-time category, nearly a quarter in all other arrangements, and 13 percent in arrangements involving labor market intermediaries.

\section{\{Place Table 4 about here\}\}}

\footnotetext{
${ }^{8}$ The important caveat here is the legal concept of a joint employer, which arises under various laws when on-site supervisors have substantial control over workers who are otherwise directly employed by an outside organization. In such cases the on-site organization and the offsite organization become jointly liable for legal issues concerning the workers.
} 
Current but less reliable data derived from the labor market intermediaries themselves paints a strikingly similar picture of the great variance in use of these practices across organizations. A 2009 survey of U.S. employers by Manpower revealed that a majority of U.S. firms do not consider the use of alternative arrangements to be a key part of their workforce strategy (Manpower 2009), and the American Staffing Association found that, on average, only 15 percent of U.S. businesses use staffing services (agency temps and leased employees) in a given year (Berchem 2011). Among other things, these results reinforce the point that the variation in the use of alternative arrangements at the organization and establishment level is perhaps the central issue in understanding these arrangements.

\section{Trends in Nonstandard Work over Time}

Unlike previous establishment level surveys, comparisons across the various versions of the NES conducted since 1994 provide an opportunity to examine trends in alternative arrangements work over time. The caveats, as noted earlier, are that the questions asked in each of the various surveys have not been entirely consistent in their wording, an issue we address below, and not all types of alternative arrangements were examined in each survey.

Nevertheless, it is possible to draw some general conclusions about trends in the use of nonstandard arrangements over time from the data.

Our initial approach involves a simple reporting of the mean use of various forms of nonstandard work in each period, repeated cross-sectional samples of the population of establishments. Because all respondents to the 2000 NES replied to the 1997 survey and a subset of the respondents replied to all three surveys, it is also possible to make comparisons of the same establishments over time. A second approach, therefore, involves looking at how mean use compares for a set of respondents over time. This approach focuses on survivors, establishments 
that were around in 1994 and survived six years later. It reveals something about how individual establishments have adapted over time, but it also excludes new establishments and those that have failed in the interim. Comparing the former approach (all respondents) to the latter (the survivors from 1994) can reveal some of the factors driving changes in the incidence of these practices within organizations and in the population. The Census conducted a small, 1000 establishment supplemental survey to the NES in 1996 drawn from respondents to the 1994 survey that asked some similar questions, and we include the results of that survey for robustness purposes.

\section{Trends across all organizations}

Table 5 reveals the use of all types of nonstandard work across the different years of the NES. Looking first at part-time work, the mean level of use declined slightly but steadily over time. The percentage of temporary workers who work directly for the establishment - excluding those employed by agencies - jumped sharply from 2.7 percent in 1994 to 4.3 percent in 1996 , and 5.7 percent in 1997 , but then dropped sharply again in 2000 , back to 2.8 percent. The rise in use during the economic boom of the 1990s is in line with the general view of temporary help as a pro-cyclical activity. ${ }^{9}$ The fact that the 2001 recession had begun (albeit barely) when the survey was being completed may have had some influence on the decline in the 2000 figures.

\section{\{\{Place Table 5 about here $\}\}$}

\footnotetext{
${ }^{9}$ The questions in the surveys explicitly ask respondents to exclude agency temps from their estimates and to only include their own "on-payroll" employees. The 1994 survey is less clear in defining temp workers. The prior question asks about the total number of the establishment's direct employees and then goes on to ask what percentage of those were temps. The 1997 and 2000 estimates explicitly include seasonal workers in the definition of on-roll temps, whereas earlier estimates do not. It is possible that respondents in the 1994 and 1996 surveys did not think of summer workers or other seasonal employees as temporary help even though seasonal workers are, in many ways, even more temporary than the typical direct hire temp: their employment will clearly stop at the end of a season (generally four months or less) whereas temps can be employed indefinitely. Any bias associated with this response, however, would not explain the sharp jump in the 1996 survey results nor the sharp decline in the 2000 results.
} 
Off-roll workers, defined as non-employees, constituted less than 1 percent of the total workforce in 1994. By 1996, however, the comparable figure rose to 4.2 percent, rising again in 1997 to 5.4 percent, where it appears to have remained steady. When we think about the structurally insecure component of nonstandard work - that is, off-roll workers as well as directhire temps whose jobs are irregular (excluding part-time employees) - the estimates from the 1994 survey suggest 3.2 percent of the total workforce was in that group. By 1996, the percentage rose quite abruptly to over 8 percent, climbing all the way past 11 percent in 1997 before declining to around 8 percent again in 2000. Again, this pattern may reflect business cycle expansion, at least until 2000.

Looking at how many employers report using any of these arrangements provides another perspective on these trends. In 1994, only 9 percent of establishments reported using any off-roll workers, and only 25 percent reported using any combination of off-role workers and direct-hire temps. By 1996, both figures had risen dramatically, to 50 percent and 65 percent, respectively. The 1997 figures are quite similar, 54 percent and 66 percent. The 2000 survey did not ask the same overall question, but the percentage of firms that report using various labor market intermediaries (ranging from the 21 percent using PEO workers to the 43 percent using agency temps - see Table 2) suggest that both percentages remained quite high in 2000.

\section{Trends within organizations}

Table 6 compares the estimates available from establishments that responded in both 1994 and 2000. Again, this restricted sample represents employers who are "survivors," those in business in 1994 and 2000, and excludes new establishments that started up after 1994 and those that failed since 1994. Changes in these results over time suggest changes in the practices of establishments rather than changes in the establishments who responded to the survey. 


\section{$\{\{$ Place Table 6 about here $\}\}$}

The results in Table 6 suggest that the use of part-time workers seems to have declined somewhat over time among the survivors while the use of direct-hire temporaries has expanded considerably, nearly doubling from 2.5 percent to 4.5 percent. More generally, the various measures of off-roll arrangements suggest only a moderate increase in their incidence, virtually all of which seems to be explained by differences at the $90^{\text {th }}$ percentile of the distribution. In other words, a small number of employers have greatly expanded their use of these practices since 1994. At the same time, we see more than a five-fold increase in the number of firms using at least one type of off-roll arrangement, suggesting that many of these establishments have begun to experiment with a small number of workers in alternative arrangements.

\section{Summary of Trends}

In addition to providing new information on aspects of direct-hire and agency temp use as well as arguably the first rigorous data on PEO and vendor use, the above descriptive results suggest some things that we did not know before. For example:

- Temp use is more extensive than previously thought

- Nonstandard arrangements of all kinds are highly skewed by establishment with a small number making very extensive use of them

- These arrangements expanded faster in the population of establishments than within individual establishments, suggesting that new establishments to the survey, possibly newer in age as well, given a representative sampling frame, made greater use of them ${ }^{10}$

\footnotetext{
${ }^{10}$ Mach and Holmes (2008) find that among a representative sample of U.S. small business (fewer than 500 employees) younger firms are the most likely to use all forms of alternative arrangements (temps, leased and contractors).
} 
- The increase in their use was not inexorable, however, as there were declines between 1997 and 2000.

What we cannot answer within the constraints of this paper is why these changes over time occurred. An obvious explanation, as noted above, relates to the business cycle. The fast rate of economic growth in late 1990 s perhaps meant that employers were prepared to commit to a higher proportion of permanent jobs. The patterns in the data reveal that such growth was associated with changes in the mix of employment arrangements (i.e. substituting permanent jobs for part-time and direct-hire temp jobs), but had little relationship with the mix of employment vs. non-employment arrangements, as the percentage of the latter increased slightly between 1996 and 1997 before leveling off in 2000. Even though the economy was still very strong in 2000 , the rate of increase in growth certainly slowed.

Given these trends, it is unfortunate that there have not been systematic efforts to collect more recent data on the use of alternative arrangements by employers. The available data, limited as it may be, does suggest that the overall patterns remained similar, even accounting for the Great Recession. While we previously noted the shortcoming with data collected at the individual level, estimates of the percentage of individuals employed each of the four alternative arrangements identified in the Current Population Survey in 2005 (the last year the data were collected) are similar to those reported in the CPS in1999 and 2001 (Table 7). If anything, the slight increases in those identifying themselves as independent contractors and on-call workers suggests that those arrangement may have become more prevalent.

Other data also indicates that client use of alternative arrangements appears to remain highly skewed, with large organizations twice as likely as smaller organizations to use temporary agency or leased workers (Figure 1: Berchem 2011). Longitudinal data on the size of the 
temporary agency industry presented in Figure 2 suggests that the use of temporary agency workers fluctuates pro-cyclically with the economy and has increased as the 2008 recession fades.

Using data from the Bureau of Labor Statistics Quarterly Census of Employment and Wages, Lou and colleagues (2010) find a similar pattern over time: after a precipitous decline during the 2001-2002 recession, the number of temporary agency workers quickly rebounded to near-peak levels from 2005-2007 before dipping sharply again in 2008. Staffing industry data show that a rapid recovery in temp agency employment began in 2010 and the first quarter of 2011 (Figure 2), with double-digit quarterly growth (Berchem 2011). Moreover, McKinsey’s 2011 U.S Jobs Survey found more than one-third of firms reporting that they anticipate using more part-time, temporary and contract workers during the next five years (Manyika et al. 2011). The pattern over time in these data seems to be expansion of these arrangements during periods of economic growth, declines during downturns, and then expansion again to new heights of use with renewed growth in the economy. This pattern reinforces what we see over time in the NES data.

\{\{Place Table 7 about here $\}\}$

$\{\{$ Place Table 8 about here $\}\}$

\{\{Place Table 9 about here $\}\}$

\section{Explaining the use of alternative arrangements}

Perhaps the most important finding in the descriptive results above is the considerable variation across establishments in their use of alternatives to standard employment, differences that surely relate to attributes of and decisions made by employers. Stating possible explanations for the variation in use is far easier than operationalizing such explanations, however. The main reason has to do with establishing causation: most every attribute of a business operation is 
capable of being changed by the employer, reversing possible causal arrangements. Even more likely is the possibility that employers make decisions about alternative working arrangements simultaneously with decisions about other practices. Longitudinal data per se does not solve these problems given that many important attributes are in place before the data begin to be collected, and such data also cannot rule out simultaneous changes.

Most of the factors examined in prior studies to explain the incidence of alternative arrangements vary along with the incidence of those arrangements, so it makes more sense to suggest that the prior hypotheses we consider below are about association rather than causation.

\section{Cost Reduction}

The first and principal explanation suggested for the use of nonstandard relationships is employers' desire to save on a variety of employment costs. The prior evidence and arguments are decidedly mixed, so exploring these explanations with the NES III seems especially warranted.

There is some evidence that employers pay workers in some alternative arrangements less than employees in comparable jobs. Temp agency workers experience a wage penalty in all occupations other than nursing, where there is a premium (Peck and Theodore 2007; Kilcoyne 2005). Yet these savings are likely to be offset in part, if not entirely, by the margins paid to staffing agencies (Peck, Theodore, and Ward 2005). Houseman, Kalleberg and Erickcek (2003) find situations where nonstandard workers are used to avoid having to raise the wages of permanent employees. Similarly, Davis-Blake, Broschak and George (2003) show that employers may contract out high wage jobs in order to avoid perceptions of internal wage inequality. Gramm and Schnell's (2001) study of Alabama manufacturing establishments found that the likelihood of contracting out certain jobs was positively related to core employee's 
wages, suggesting that where the costs of standard work arrangements are higher, we may expect to see higher use of nonstandard arrangements. The Federal Fair Labor Standards Act requires firms to pay non-exempt workers time and half for overtime hours, with exemptions for nonemployees (Coens and Storrs 2006). Firms that make more use of overtime hours may therefore have a greater incentive to save on wages by using nonstandard workers to cover those hours, even if they are paid a comparable base wage. ${ }^{11}$

While employers may save on wages, the most important compensation savings may concern the provision of benefits, as non-employees are not required to receive the same benefits as full-time employees. ${ }^{12}$ As a result, there appear to be greater incentives for employers that offer more generous benefit packages to make more use of nonstandard arrangements in an effort to cut costs. Lautsch (2003) shows that many companies use nonstandard workers to avoid paying for healthcare and other fringe benefits, and Peck and Theodore (1998) find that some employers use agency temps to save on overall compensation (including benefits). Mitlacher's (2007) fieldwork in American banking and catering firms revealed that the use of temp agency workers was driven in part by the fact that these workers did not have to be included in the companies' retirement and pension plans.

Yet, HR managers consistently report in recent years that that they do not use these arrangements to save on employee benefits (Houseman 2001; Kalleberg et al. 2003). While such responses may be subject to social desirability bias, establishment-level surveys have shown that

\footnotetext{
${ }^{11}$ The use of overtime hours may also indicate the need for numeric flexibility, which we address below.

12 The Employee Retirement Income Security Act (ERISA) and Internal Revenue Service regulations require that if employers offer pension, health insurance, and other employee benefits that have preferential tax status to any employees, they must make them available to all regular, full-time employees. These benefits typically increase total compensation by 25 to 40 percent (Muhl 2002). Exceptions are allowed for workers who work fewer than what has traditionally been seen as regular hours, effectively exempting part-time workers, and tenure eligibility requirements (e.g., waiting six months before becoming eligible for certain benefits) are also allowed, effectively exempting many direct-hire temporary workers. Workers who are not employees - contractors and agency temps, e.g. - are not eligible for employment-related benefits.
} 
the scale of benefits offered does not predict that use of nonstandard arrangements (Kalleberg et al. 2003). Houseman (2001) finds that offering good benefits predicts the use of temp agency workers but not independent contractors, even though both are non-employee arrangements, as well as predicting the use of part-time and on-call workers, but not direct-hire temps, even though all are employment arrangements. Reverse causation might be a possible explanation (e.g., greater use of temps makes it easier to provide more generous benefits to the fewer regular employees).

To test the cost savings hypotheses, we see whether establishments that have higher pay, use more overtime hours, and offer more benefits, other things equal, make greater use of alternative arrangements.

\section{Flexibility}

The second common explanation for the use of alternative arrangements is that they provide employers with greater "numerical" flexibility, the ability to adjust the amount of workers being used (Smith 1997; Kalleberg 2000). Surveys of human resource managers report that all nonstandard work arrangements are used to meet variations in demand, and firms in seasonal industries make greater use of most nonstandard arrangements, though industry cyclicality seems to have no effect on their use (Houseman 2001; Kalleberg et al. 2003). McLaughlin and Coleman-Jensen (2008) note that in agriculture, a notoriously seasonal industry, 45 percent of work arrangements are nonstandard. Lombardi and Ono (2008) find that new manufacturing plants, which may be more likely to face more uncertain demand, are more likely to used leased employees. They also find the highest rate of use in the transportation industry, an industry especially sensitive to fluctuations in demand. 
Restructuring decisions associated with the term "reengineering" in the late 1990s, downsizing decisions, and outsourcing may also reflect business uncertainty and create uncertainty in labor needs. Employers began to add temporary agency workers while laying off permanent employees during the period of widespread downsizing and reengineering following the 2001 recession (Peck and Theodore 2007). More directly, Screft and Sigh (2003) conclude that substituting nonstandard for more permanent arrangements is a strategy used by firms to meet increases in demand following layoffs.

Establishments may also turn to nonstandard arrangements for numerical flexibility when the fixed costs of hiring and dismissing workers make it more expensive to adjust the number of standard employees. Using temps allows employers to dismiss the temps that are not suitable for full-time jobs without the risk of violating employment laws, which apply only to direct employees $^{13}$ and then hire those who are suitable into regular employment (see Miles 2000; Davis-Blake and Broschak 2000). Houseman and colleagues (2003) find that using agency temps allows firms to sample riskier employees in low skill occupations. Gramm and Schnell (2001) found that the use of nonstandard arrangements was positively associated with the hiring costs for permanent employees in their sample of manufacturing firms. Severance pay is one clear factor that makes dismissals more expensive.

It has been suggested that the presence of a union may increase the employer's interest in using of nonstandard arrangements to get around union work, but may decrease the employer's ability to do so by resisting the changes in collective bargaining (see Kalleberg et al. 2003 for a summary of this debate; Davis-Blake and Uzzi 1993, Theodore and Peck 2002, and Lombardi and Ono 2008 for evidence).

\footnotetext{
${ }^{13}$ Again, the exception is if a client of a vendor or independent contractor directs such workers in ways that make them effectively employees. In that case, the client can become a co-employer, liable for the provisions of employment law.
} 
The NES III data includes several measures associated with the need for greater flexibility, as reflected in the above hypotheses: Seasonal employment variability, reengineering in the last 3 years, a downsizing or outsourcing of a portion of their workforce in the past 12 months, whether or not they offered severance packages to standard employees, and their average recruiting costs. The survey also asks whether any of the firm's employees are represented by a union.

\section{Ability to Use Nonstandard Workers}

Non-employees are governed by contracts that specify job requirements and effort levels in advance, performance is monitored by the client, and disputes are ultimately adjudicated by the court system. As a result, alternative arrangements make the most sense for employers when performance requirements are straightforward and easy to specify and where monitoring those requirements is straightforward as well. Masters and Miles' (2002) multi-firm analysis of hiring decisions revealed that firms are more likely to use off-roll arrangements in positions where performance is easy to assess. Mayer and Nickerson (2005) similarly find that firms are more likely to use regular employees than independent contractors as the cost to verify project quality increases. In her qualitative study of the use of contingent workers, Lautsch (2002) found that in half of the firms, contingent workers were assigned to positions that had more narrowly defined tasks than regular workers. To the extent that supervisors monitor the performance of tasks by individual workers, jobs are likely to require less monitoring where the ratio of workers to supervisors is high. Teamwork may represent the opposite situation, where individual tasks are hard to define and had to monitor and where it is difficult to insert workers on a temporary or casual basis. Firm-specific skill requirements may also make it more difficult to use nonstandard arrangements. Training expenditures may represent something about firm-specific skills. 


\section{Analysis and results}

We examine the above hypotheses with regression analyses shown in Table 9, using the independent variables described in Table 8 to test the hypotheses described above. Access limitations at Census restricted the analyses to the 2000/2001 data. Because of the difficulty in doing follow-up analyses of the data, these results should best be considered as preliminary.

The dependent variable in each case is a percentage of the workforce, bounded between zero and 100, in a given arrangement. We know from the descriptive data presented earlier that many establishments use no alternative arrangements while a few use them a great deal. It is quite likely, then, that many observations will be at or near the limits of zero and 100 percent. Ordinary least square regressions would be biased when the range of observations is constrained in that manner, and Tobit estimation techniques are more appropriate. The coefficients on such estimates cannot be interpreted in a straightforward fashion, however. ${ }^{14}$

Columns 3, 4, 5, and 6 in Table 9 represent specific alternative arrangements while column 1 represents all arrangements other than full-time, standard employment, and column 2 represents those associated with contingent work (i.e., everything but part-time work). Smaller establishments (the omitted category is more than 1000 employees) make less use of these arrangements. ${ }^{15}$ More generally, the relationships differ across the types of nonstandard work, no doubt reflecting the different attributes associated with each arrangement. For example, the factors that are associated with using agency temps are different from those associated with using direct hire temps, perhaps suggesting that they are substitutes for each other.

\footnotetext{
${ }^{14}$ Weighting the observations based on weights representing the actual distribution of establishments by industry in the economy typically improves the results considerably. Weighted Tobit regression requires nonstandard software that was not available at CES when these analyses were conducted. The Appendix contains descriptive statistics for the subsample used in the regression analysis as the original sample is reduced because of missing data.

${ }^{15}$ Among control variables not reported, manufacturing industries make greater use of alternative arrangements than non-manufacturing, establishments with more women have significantly more nonstandard work as do those with a higher level of education in their workforce.
} 


\section{Cost Reduction}

There is no support in these results for the notion that higher pay and greater employee benefits are associated with greater use of alternative arrangements. Indeed, significant results are often in the opposite direction. While we do not have good measures as to how generous benefits are, we do have a simple count as to how many benefits the employer offered ("Benefits") ${ }^{16}$. Perhaps surprisingly, the more benefits an establishment offered, the less they made use of nonstandard work.

The ratio of overtime hours ("Overtime Hours"), however, is significantly related to the incidence of nonstandard work. Presumably higher overtime hours suggest an opportunity to avoid overtime pay rates by using nonstandard jobs, especially off-role workers. Average weekly hours worked by all workers in the establishment ("Average Hours") are also positively related to nonstandard work, but average weekly hours specifically for non-managers/nonexempt workers, who are the focus of these practices ("Worker Hours"), are not.

\section{Flexibility}

At the two-digit industry level, we use the standard deviation of employment over the course of the year 2000 to measure industry seasonality ("Seasonality") and find that establishments in industries with greater variance in employment over the course of the year are associated with greater use of nonstandard employment. A second set of variables that may proxy for flexibility are major restructurings. We might think of these as more "one-shot" variations than seasonality. Reengineering in the past three years ("Reengineered") and downsizing in the past 12 months ("Downsized"), which change organizational structure and job

\footnotetext{
${ }^{16}$ The list of benefits includes pensions, healthcare, dental care, child care, leave for family emergencies (presumably beyond what is required by law), life insurance, sick pay, paid vacations, and severance pay (estimated separately). While not a perfect estimate of how generous benefits are, it is similar to the scale of benefits score used by Kalleberg et al. (2003), and arguably better than the categorical responses used in the Upjohn survey (see Houseman 2001).
} 
definitions, are not associated with overall use of nonstandard or contingent work, but they do seem to be strongly associated with the use of PEO's. Perhaps it is easier to move workers to PEO status, a radical change, in the context of these other big changes or that it is easier to make all these changes simultaneously. There is no relationship with outsourcing decisions ("Outsourced") and therefore no evidence as to whether alternative arrangements are either substitutes or complements for outsourcing.

We examine the fixed costs of hiring workers with the average amount of money spent on recruiting and hiring a full-time employee ("Recruiting Costs") and find that it is positively associated with most of the alternative arrangements, suggesting that employers do make greater use of nonstandard employees when it costs more to higher regular employees. The one aspect of nonstandard work for which the relationship is not significant is for the use of agency temps, which may be surprising because employers use agency temps as an alternative means for hiring regular employees. There is no relationship with the use of severance pay ("Severance"), which raises the costs of involuntary dismissal, and these alternative arrangements.

We find that unionization is associated with less use of nonstandard arrangements, having the largest negative effect on the use of agency temps. The coefficient for the direct hire temps is positive but insignificant, while the coefficients for all off-roll arrangements are negative, suggesting that unions primarily restrict the use of off-roll arrangements. Perhaps the reason is that off-role workers are not eligible to join the union.

\section{Ability to Use Nonstandard Arrangements}

We examine the ability to monitor work and workers with the span of control ("Worker to Supervisor Ratio") and find that greater span is associated with greater use of nonstandard arrangements. Establishments that use more firm-specific skills as measured by training 
expenditures per worker ("Training Investments") are associated with less use of nonstandard work. The relationships with teamwork ("Teamwork") are surprisingly positive with the overall use of non-standard arrangements, suggesting that nonstandard work is more common where teamwork is more common.

\section{Summary and conclusions}

Overall, the descriptive results suggest that nonstandard work accounts for a sizeable component of the actual work done inside U.S. establishments every day, that while growing, the increase has not been inexorable over time, and that the variation of use across establishments is quite remarkable. Perhaps the most surprising results are those suggesting that few establishments actually use these alternative work arrangements but that many of those that do use them very intensively. Attributes unique to individual establishments appear to be powerfully related to the extent such arrangements are used.

Our regression results examine the most prominent arguments concerning the factors associated with the use of alternative arrangements across operations. Some of them do not support prior views, such as the lack of evidence for the idea that employers use alternative arrangements to economize on wage and benefit costs, with the exception of increased use where overtime is greater. We find some support for the currently popular notion that establishments use alternative work arrangements to gain flexibility, as use is greater where industry employment has been more variable, but the only significant relationship with the proxies for restructuring is with contingent work, agency temps in particular.

Some of the results help settle arguments where hypotheses ran in opposite directions, such as whether unions increase or decrease the use of these practices (we find on average that they decrease them). Perhaps our most novel results concern the idea that these arrangements are 
used more where jobs are easier to monitor. Nonstandard work is used more where jobs appear easier to monitor and less firm-specific, although we find unexpected associations with the teamwork proxy.

It is important to recognize that the measures used here are imperfect and certainly incomplete proxies for many of the hypotheses being tested. For example, the common-sense idea that establishments will make greater use of nonstandard arrangements when they are cheaper than regular employment requires knowing much more than we do here about all aspects of the costs of standard employment and the nonstandard alternatives. Measures of average practices, such as teamwork, may not be capturing the most relevant aspects of whether jobs can be monitored. Perhaps the non-team jobs in such establishments are especially suited to nonstandard arrangements that support the teams. These concerns suggest the continuing need for more detailed, fine-grained studies, perhaps at the expense of generalizability, that can examine more of the relevant factors.

Going forward, arguably the most important of the persistent questions concerning alternatives to standard work is to pin down causation. Can we find contexts where we can see clearly what factors may be driving their use and specifically the change in use over time both within and across establishments? Other, more novel questions concern how these arrangements affect other aspects of business operations. For example, what else changes when employers expand the use of these practices? These and related questions will no doubt benefit from more context-specific data within operations and organizations. 
Table 1: Sampling Frame for the NES III

\begin{tabular}{l|c|c} 
& $\begin{array}{c}\text { Completed surveys in 1997 } \\
\text { (NES II) }\end{array}$ & $\begin{array}{c}\text { Completed surveys in 1994 \& 1997 } \\
\text { (NES I \& NES II) }\end{array}$ \\
\hline Establishments surveyed & 3,463 & 915 \\
\hline Usable responses & 2,825 & 814 \\
\hline
\end{tabular}

Table 2: Use of Nonstandard Arrangements in 2000 from the NES III

\begin{tabular}{|c|c|c|c|c|}
\hline \multirow{2}{*}{ Type of Arrangement } & \multirow{2}{*}{$\begin{array}{c}\% \text { of } \\
\text { establishments }\end{array}$} & \multirow{2}{*}{$\mathbf{n}$} & \multicolumn{2}{|c|}{ Percentage of average establishment's workforce } \\
\hline & & & \% of all employees ${ }^{a}$ & $\%$ of all on-site workers ${ }^{b}$ \\
\hline Part-time & $\mathrm{n} / \mathrm{a}$ & 2,943 & $15.76 \%$ & $15.48 \%$ \\
\hline Direct hire temporary & $22.58 \%$ & 2,967 & $2.77 \%$ & $2.59 \%$ \\
\hline \multicolumn{2}{|c|}{ Total "on-roll" arrangements: } & & $18.53 \%$ & $18.07 \%$ \\
\hline Agency temporary & $42.73 \%$ & 2,949 & $\mathrm{n} / \mathrm{a}$ & $2.14 \%$ \\
\hline Independent contractor & $35.05 \%$ & 2,816 & $\mathrm{n} / \mathrm{a}$ & $1.49 \%$ \\
\hline PEO & $21.35 \%$ & 2,871 & $\mathrm{n} / \mathrm{a}$ & $0.87 \%$ \\
\hline Vendor on premise & $39.57 \%$ & 2,949 & $\mathrm{n} / \mathrm{a}$ & $0.86 \%$ \\
\hline \multicolumn{2}{|c|}{ Total "off-roll" arrangements: } & & & $5.36 \%$ \\
\hline \multicolumn{3}{|c|}{ Total nonstandard arrangements } & & $23.43 \%$ \\
\hline
\end{tabular}

a Includes all workers on the establishment's payroll - i.e. "on-roll" workers

b Includes “on-roll workers" plus agency temps, independent contractors, PEO workers and VOP workers

Table 3: Detailed Data on Use of Agency Temps from the NES III

\begin{tabular}{lccc}
\hline & \multicolumn{2}{c}{ \% of all on-site workers } \\
& $\mathbf{n}$ & Use in peak week & Converted agency temps \\
\hline All establishments & 2,910 & $3.67 \%$ & $1.73 \%$ \\
Establishments using agency temps only & 1,221 & $8.75 \%$ & $4.46 \%$ \\
Type of job & n & \% of all agency temps \\
\hline Production jobs & 1,252 & $43.69 \%$ \\
Office jobs & 1,250 & $41.22 \%$ \\
Technical jobs & 1,251 & $10.24 \%$ \\
Managerial and professional jobs & 1,254 & $3.99 \%$ \\
Supervisor jobs & 1,253 & $0.79 \%$ & \\
\hline
\end{tabular}

${ }^{a}$ Includes "on-roll workers" plus agency temps, independent contractors, PEO workers and VOP workers 
Table 4: Distribution of Use of Alternative Arrangements as a Percentage of On-site Workers from the NES III

\begin{tabular}{lcccccc}
\hline & Median & $\begin{array}{c}25 \text { th } \\
\text { percentile }\end{array}$ & $\begin{array}{c}75 \text { th } \\
\text { percentile }\end{array}$ & $\begin{array}{c}\text { 90th } \\
\text { percentile }\end{array}$ & $\begin{array}{c}\text { 95th } \\
\text { percentile }\end{array}$ & $\begin{array}{c}\text { 99th } \\
\text { percentile }\end{array}$ \\
\cline { 2 - 6 } Part time & $3.7 \%$ & $0.0 \%$ & $23.6 \%$ & $50.1 \%$ & $65.7 \%$ & $89.5 \%$ \\
Direct-hire temporary & $0.0 \%$ & $0.0 \%$ & $0.7 \%$ & $10.9 \%$ & $29.1 \%$ & $96.6 \%$ \\
Agency temporary & $0.0 \%$ & $0.0 \%$ & $1.3 \%$ & $5.5 \%$ & $10.0 \%$ & $21.9 \%$ \\
Independent contractor & $0.0 \%$ & $0.0 \%$ & $0.6 \%$ & $2.9 \%$ & $6.8 \%$ & $30.2 \%$ \\
PEO & $0.0 \%$ & $0.0 \%$ & $0.0 \%$ & $1.7 \%$ & $4.9 \%$ & $15.9 \%$ \\
Vendor on premise & $0.0 \%$ & $0.0 \%$ & $0.6 \%$ & $3.2 \%$ & $7.3 \%$ & $27.2 \%$ \\
\hline
\end{tabular}

Table 5: Trends in Use of Alternative Arrangements Across NES Samples

\begin{tabular}{llcccc}
\hline \multicolumn{2}{l}{ Use as \% of on-roll/employees } & $\mathbf{1 9 9 4}$ & $\mathbf{1 9 9 6}$ & $\mathbf{1 9 9 7}$ & $\mathbf{2 0 0 0}$ \\
\hline \multirow{2}{*}{ Part time } & Mean & $17.92 \%$ & $16.24 \%$ & $16.66 \%$ & $15.76 \%$ \\
& Median & $5.20 \%$ & $3.60 \%$ & $4.00 \%$ & $4.04 \%$ \\
\multirow{2}{*}{ Direct-hire temporary } & Mean & $2.66 \%$ & $4.28 \%$ & $5.73 \%$ & $2.77 \%$ \\
& Median & $0.00 \%$ & $0.00 \%$ & $0.00 \%$ & $0.00 \%$ \\
\multirow{2}{*}{ Off-roll workers } & Mean & $0.51 \%$ & $4.15 \%$ & $5.35 \%$ & $5.36 \%$ \\
\multirow{2}{*}{$\%$ of establishments reporting use } & $\mathbf{1 9 9 4}$ & $\mathbf{1 9 9 6}$ & $\mathbf{1 9 9 7}$ & $\mathbf{2 0 0 0}$ \\
\hline Off-roll workers & Median & $9.00 \%$ & $0.11 \%$ & $0.83 \%$ & $0.00 \%$ \\
\multicolumn{2}{l}{ Off-roll + Temp workers } & $25.00 \%$ & $65.00 \%$ & $66.00 \%$ & $\mathrm{n} / \mathrm{a}$ \\
\hline
\end{tabular}


Table 6: Trends in Use of Alternative Arrangements Among Surviving Firms

\begin{tabular}{llcc}
\hline Use as \% of on-roll workers & $\mathbf{1 9 9 4}$ & $\mathbf{2 0 0 0}$ \\
\hline \multirow{3}{*}{ Part time } & Mean & $20.4 \%$ & $15.6 \%$ \\
& Median & $5.9 \%$ & $3.1 \%$ \\
& 75th percentile & $31.0 \%$ & $24.0 \%$ \\
& 90th percentile & $70.0 \%$ & $53.0 \%$ \\
Direct-hire & Mean & $2.5 \%$ & $4.5 \%$ \\
temporary & Median & $0.0 \%$ & $0.0 \%$ \\
& 75th percentile & $0.0 \%$ & $1.1 \%$ \\
& 90 th percentile & $3.2 \%$ & $13.0 \%$ \\
Off-roll workers & Mean & $3.2 \%$ & $3.5 \%$ \\
& Median & $0.0 \%$ & $0.9 \%$ \\
& 75th percentile & $0.0 \%$ & $3.9 \%$ \\
\% of firms reporting use & $5.4 \%$ & $11.0 \%$ \\
\hline Off-roll workers & & $\mathbf{1 9 9 4}$ & $\mathbf{2 0 0 0}$ \\
Off-roll + Temp workers & $10.0 \%$ & $56.0 \%$ \\
\hline
\end{tabular}


Table 7: CPS Estimates of Workers in Alternative Arrangements

\begin{tabular}{|c|c|c|c|c|c|c|}
\hline \multirow[b]{2}{*}{$\begin{array}{l}\text { Alternative Work } \\
\text { Arrangement }\end{array}$} & \multirow[b]{2}{*}{ Definition } & \multicolumn{5}{|c|}{ Percent of total workers employed } \\
\hline & & $\begin{array}{l}\text { Feb } \\
1995\end{array}$ & $\begin{array}{l}\text { Feb } \\
1997\end{array}$ & $\begin{array}{l}\text { Feb } \\
1999\end{array}$ & $\begin{array}{l}\text { Feb } \\
2001\end{array}$ & $\begin{array}{l}\text { Feb } \\
2005\end{array}$ \\
\hline Independent contractors & $\begin{array}{l}\text { Workers who were identified as independent contractors, independent } \\
\text { consultants, or freelance workers, whether they were self-employed or } \\
\text { wage and salary workers. }\end{array}$ & 6.7 & 6.7 & 6.3 & 6.4 & 7.4 \\
\hline On-call workers & $\begin{array}{l}\text { Workers who are called to work only as needed, although they can be } \\
\text { scheduled to work for several days or weeks in a row. }\end{array}$ & 1.7 & 1.6 & 1.5 & 1.6 & 1.8 \\
\hline $\begin{array}{l}\text { Temporary help agency } \\
\text { workers }\end{array}$ & $\begin{array}{l}\text { Workers who were paid by a temporary help agency, whether or not their } \\
\text { job was temporary. }\end{array}$ & 1.0 & 1.0 & 0.9 & 0.9 & 0.9 \\
\hline $\begin{array}{l}\text { Workers provided by } \\
\text { contract firms }\end{array}$ & $\begin{array}{l}\text { Workers who are employed by a company that provides them or their } \\
\text { services to others under contract and who are usually assigned to only one } \\
\text { customer and usually work at the customer's worksite. }\end{array}$ & 0.5 & 0.6 & 0.6 & 0.5 & 0.6 \\
\hline
\end{tabular}

Source: Current Population Survey, Bureau of Labor Statistics

Figure 1: Percentage of Firms Using Temporary Agency or Leased Workers by Firm Size

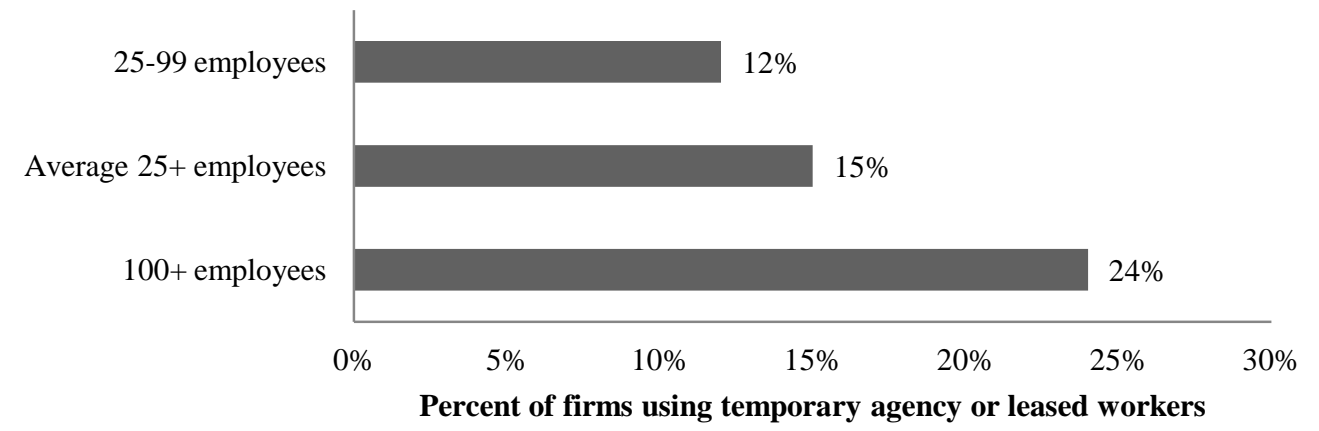

Source: American Staffing Association, Client Survey (ASA, 2011) 
Figure 2: Temporary Staffing Agency Average Daily Employment (Millions)

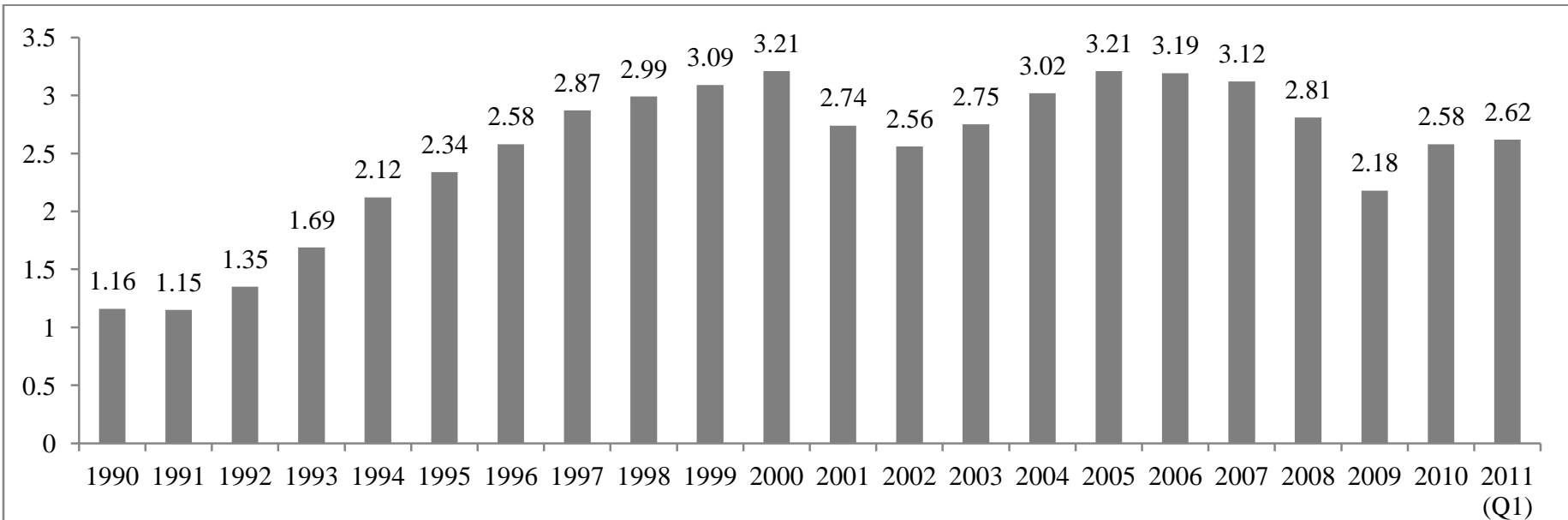

Source: American Staffing Association, Employment and Sales Survey (ASA, 2011) 
Table 8: Description of Independent and Control Variables

\begin{tabular}{|c|c|}
\hline Independent Variables & Description \\
\hline Average pay (all jobs) & Average annual income for all workers (000s) \\
\hline Worker pay (non-managerial) & Average hourly pay for non-managerial workers \\
\hline Benefits & Count of the number of benefits offered, excluding severance \\
\hline Seasonality & Industry standard deviation of employment during the year 2000 \\
\hline Reengineered (dummy) & Establishment experienced a major restructuring in the previous 3 years \\
\hline Downsized (dummy) & Establishment experienced downsizing in the previous 12 months \\
\hline Outsourced (dummy) & Establishment has outsourced one or more function in the previous 12 months \\
\hline Overtime Hours & $\begin{array}{l}\text { Average overtime hours for non-managerial workers (as a ratio of regular } \\
\text { hours) }\end{array}$ \\
\hline Average hours (all jobs) & Average hours/week for all workers \\
\hline Worker hours (non-managerial) & Average hours/week for non-managerial workers \\
\hline Recruiting costs & Average recruiting costs per worker \\
\hline Severance (dummy) & Organization offers severance pay as a benefit \\
\hline Union (dummy) & Indicates the presence of one or more unions \\
\hline Training investments & Average annual training expenditure per worker \\
\hline Worker to supervisor ratio & Ratio of workers to supervisors \\
\hline Teamwork ( $\%$ of jobs $)$ & Percentage of jobs reported as being organized in teams \\
\hline \multicolumn{2}{|l|}{ Control Variables } \\
\hline Establishment size & Total number of employees (omitted category is $>1000$ employees) \\
\hline Multi-establishment (dummy) & Establishment is part of a firm with multiple establishments \\
\hline Temp services industry (736) & Establishment is part of the temp-services industry \\
\hline Female ( $\%$ of workers) & Percentage of female workers \\
\hline Minority (\% of workers) & Percentage of non-white workers \\
\hline Average years of education & Average years of education for all workers \\
\hline Located in South (dummy) & Located in AL, AR, DE, KY, FL, GA, LA, MD, MS, NC, OK, SC, TN, TX, VA \\
\hline
\end{tabular}


Table 9: Tobit Regression Models Predicting the Use of Nonstandard Work Arrangements ${ }^{\mathrm{a}}$

\begin{tabular}{|c|c|c|c|c|c|c|c|c|c|c|c|c|}
\hline & \multicolumn{2}{|c|}{$\begin{array}{l}\text { All Nonstandard } \\
\text { Arrangements }\end{array}$} & \multicolumn{2}{|c|}{$\begin{array}{c}\text { Contingent } \\
\text { Arrangements }\end{array}$} & \multicolumn{2}{|c|}{$\begin{array}{l}\text { Agency Temp } \\
\text { Workers }\end{array}$} & \multicolumn{2}{|c|}{$\begin{array}{l}\text { Direct-hire Temp } \\
\text { Workers }\end{array}$} & \multicolumn{2}{|c|}{$\begin{array}{l}\text { PEO (Leased) } \\
\text { Workers }\end{array}$} & \multicolumn{2}{|c|}{$\begin{array}{l}\text { Independent } \\
\text { Contractors }\end{array}$} \\
\hline & $\underline{\boldsymbol{b}}$ & s.e. & $\underline{b}$ & s.e. & $\underline{b}$ & s.e. & $\underline{b}$ & s.e. & $\underline{b}$ & s.e. & $\underline{b}$ & s.e. \\
\hline Less than 50 employees & $-8.03 * *$ & 1.8 & $-9.92 * *$ & 1.7 & $-14.69 * *$ & 2.1 & $-21.73 * *$ & 3.5 & $-6.23 *$ & 2.8 & $-8.32 * *$ & 2.4 \\
\hline 50-99 employees & $-3.88 *$ & 1.6 & $-3.78^{*}$ & 1.6 & $-10.30 * *$ & 1.9 & $-14.66^{* *}$ & 3.1 & 1.23 & 2.5 & $-5.63 *$ & 2.2 \\
\hline 100 to 249 employees & $-3.85 * *$ & 1.5 & $-3.54 *$ & 1.4 & $-5.51 * *$ & 1.6 & $-9.03 * *$ & 2.7 & $-4.05 \dagger$ & 2.4 & $-6.29 * *$ & 2.0 \\
\hline 250 to 1000 employees & $-2.67 *$ & 1.3 & -1.37 & 1.2 & $-2.36 \dagger$ & 1.4 & $-4.60 *$ & 2.3 & -1.4 & 2.0 & $-3.75^{*}$ & 1.7 \\
\hline Multi-establishment (dummy) & 0.68 & 0.9 & 0.84 & 0.9 & $2.57 *$ & 1.1 & -0.29 & 1.8 & $-4.44 * *$ & 1.5 & $4.28 * *$ & 1.3 \\
\hline Temp Services Industry (736) & $57.55^{* *}$ & 5.6 & $62.83 * *$ & 5.2 & & & 71.82 & 8.9 & & & & \\
\hline Female ( $\%$ of workers) & $6.50 * *$ & 2.2 & 0.44 & 2.1 & 1.03 & 2.6 & 4.41 & 4.2 & 3.96 & 3.5 & -0.51 & 3.2 \\
\hline Minority (\% of workers) & -0.83 & 1.7 & 2.58 & 1.6 & $4.67 *$ & 2.0 & $-7.93 *$ & 3.3 & $5.14 \dagger$ & 2.6 & $4.33 \dagger$ & 2.3 \\
\hline Average Years of Education & $0.81 \dagger$ & 0.5 & $0.96^{*}$ & 0.5 & $1.03 \dagger$ & 0.6 & 1.06 & 0.9 & $2.22 * *$ & 0.8 & 0 & 0.7 \\
\hline Located in South (dummy) & $-1.69 \dagger$ & 1.0 & 0.78 & 1.0 & 1.57 & 1.2 & -2.75 & 2.0 & 0.39 & 1.6 & 0.22 & 1.4 \\
\hline Average Pay (all jobs) & 2.92 & 3.1 & 3.82 & 3.0 & $11.17 * *$ & 3.7 & 5.05 & 5.7 & 2.51 & 5.0 & 2 & 4.4 \\
\hline Worker Pay (non-managerial) & $-8.19 * *$ & 3.0 & -4.04 & 3.0 & $-9.99 * *$ & 3.6 & -8.80 & 5.6 & -3.03 & 4.9 & 4.56 & 4.4 \\
\hline Benefits & $-0.88 * *$ & 0.3 & $-0.64 *$ & 0.3 & 0.09 & 0.4 & $-1.84 * *$ & 0.5 & $1.15^{*}$ & 0.5 & -0.24 & 0.4 \\
\hline Seasonality & $52.57 *$ & 25.6 & $10.18 * *$ & 2.6 & -1.43 & 32.5 & $21.47 * *$ & 4.4 & & & & \\
\hline Reengineered (dummy) & 0.69 & 0.8 & 0.07 & 0.8 & 0.2 & 0.9 & -1.05 & 1.5 & $3.72 * *$ & 1.2 & -1.04 & 1.1 \\
\hline Downsized (dummy) & -0.22 & 0.9 & -0.67 & 0.8 & -0.35 & 1.0 & -2.02 & 1.7 & $2.89^{*}$ & 1.3 & -0.86 & 1.2 \\
\hline Outsourced (dummy) & 0.8 & 0.8 & $2.01 * *$ & 0.8 & $1.96^{*}$ & 0.9 & 1.97 & 1.5 & 1.17 & 1.3 & $1.79 \sim$ & 1.1 \\
\hline Overtime Hours & $51.54 * *$ & 7.4 & 6.44 & 7.3 & 2.16 & 11.0 & -2.94 & 14.3 & 2.98 & 11.8 & -4.39 & 12.3 \\
\hline Average Hours (all jobs) & -9.75 & 8.5 & $-17.98 *$ & 8.1 & 0.27 & 11.0 & 22.57 & 19.1 & $-59.72 * *$ & 11.9 & -8.87 & 11.5 \\
\hline Worker Hours (non-managerial) & $-27.34 * *$ & 8.4 & $15.38 \dagger$ & 8.2 & 0.58 & 12.0 & -23.88 & 17.7 & $54.43 * *$ & 12.9 & 16.11 & 12.0 \\
\hline Recruiting Costs & $0.57 * *$ & 0.2 & $0.75^{* *}$ & 0.2 & $0.47 *$ & 0.2 & 0.43 & 0.3 & $0.97 * *$ & 0.3 & $0.47 *$ & 0.2 \\
\hline Severance (dummy) & 0.09 & 0.8 & 0.55 & 0.8 & -0.39 & 1.0 & $3.16 \dagger$ & 1.6 & $-3.06 *$ & 1.4 & -0.53 & 1.2 \\
\hline Union (dummy) & $-2.90 *$ & 1.2 & $-3.29 * *$ & 1.2 & $-7.57 * *$ & 1.4 & 2.95 & 2.3 & -1.32 & 2.0 & -1.21 & 1.7 \\
\hline Worker to Supervisor ratio & $-0.45^{*}$ & 0.2 & $-0.37 *$ & 0.2 & $-0.42 \dagger$ & 0.2 & -0.03 & 0.0 & -0.01 & 0.0 & $-0.69^{*}$ & 0.3 \\
\hline Training Investments & $-0.42 *$ & 0.2 & $-0.35 \dagger$ & 0.2 & -0.05 & 0.2 & $-1.53 * *$ & 0.4 & -0.28 & 0.3 & $0.68 *$ & 0.3 \\
\hline Teamwork ( $\%$ of jobs) & $2.64 *$ & 1.3 & 1.63 & 1.3 & 1.48 & 1.5 & 2.17 & 2.6 & 1.21 & 2.1 & 0.9 & 1.8 \\
\hline Constant & $17.86^{* *}$ & 3.9 & -42.42 & 37.8 & -55.49 & 51.3 & -11.72 & 7.3 & -33.14 & 61.2 & -5.55 & 59.2 \\
\hline Observations & \multicolumn{2}{|c|}{2,073} & \multicolumn{2}{|c|}{2,005} & \multicolumn{2}{|c|}{2,095} & \multicolumn{2}{|c|}{2,082} & \multicolumn{2}{|c|}{2,062} & \multicolumn{2}{|c|}{2,034} \\
\hline Log Likelihood & \multicolumn{2}{|c|}{-7763.25} & \multicolumn{2}{|c|}{-6228.22} & \multicolumn{2}{|c|}{-4261.53} & \multicolumn{2}{|c|}{-2595.9} & \multicolumn{2}{|c|}{-2501.16} & \multicolumn{2}{|c|}{-3679.45} \\
\hline
\end{tabular}

${ }^{\text {a }}$ Industry variables not reported. Other controls not reported are area population, employment, and income, urban employment, telecommuting policies \& establishment annual income.

$* \mathrm{p}<0.01, * \mathrm{p}<0.05, \dagger \mathrm{p}<0.10$ 


\section{References}

Abraham, Katharine G. 1990. Restructuring the employment Relationship: The growth of market-mediated work arrangements. New developments in the labor market: Toward a new institutional paradigm, edited by Katharine G. Abraham and R. B. McKersie. Cambridge, MA: MIT Press.

Abraham, Katharine G., and Susan K. Taylor. 1996. Firms' use of outside contractors: Theory and evidence. Journal of Labor Economics 14(3):394-424.

Autor, David H. 2003. Outsourcing at will: The contribution of unjust dismissal doctrine to the growth of employment outsourcing. Journal of Labor Economics 21(1):1-42.

Autor, David H., and Susan N. Houseman. 2006. Temporary agency employment as a way out of poverty? Working and poor: How economic and policy changes are affecting low-wage workers, edited by Rebecca M. Blank, Sheldon Danziger, and Robert F. Schoeni. New York: Russell Sage Foundation.

Belman, Dale L., and Lonnie Golden. 2000. Nonstandard and contingent employment: Contrasts by job type, industry, and occupation. Nonstandard work: The nature and challenges of changing employment arrangements, edited by F. Carre, M. A. Ferber, L. Golden, and S. A. Herzenberg. Champaign, IL: Industrial Relations Research Association.

Berchem, Steven P. 2011. Leading U.S. Job Growth.

Cappelli, Peter. 2000. Market-mediated employment: The historical context. The new relationship: Human capital and the American corporation, edited by Margaret Blair and Thomas A. Kochan. Washington, D.C.: The Brookings Institution.

Cappelli, Peter. 1999. The new deal at work: Managing the market-driven workforce. Boston, MA: Harvard Business School Press.

Cappelli, Peter, and JR Keller. 2013. Classifying work in the new economy. Academy of Management Review (forthcoming)

Coens, Thomas A., and Alvin L. Storres. 2006. No safe harbor: A review of significant laws affecting contingent workers. The shadow workforce: Perspectives on contingent work in the United States, Europe, and Japan, edited by Sandra E. Gleason. Kalamazoo, MI: W.E. Upjohn Institute.

Davis-Blake, Alison, and Joseph P. Broschak. 2000. Speed bumps or stepping stones: The effect of labor market intermediaries on relational wealth. Relational wealth: A new model for employment in the 21st century, edited by Denise Rousseau and C Leana. New York: Oxford University Press.

Davis-Blake, Alison, Joseph P. Broschak, and Elizabeth George. 2003. Happy together? How using nonstandard workers affects exit, voice, and loyalty among standard employees. Academy of Management Journal 46(4):475-485.

Davis-Blake, Alison, and Brian Uzzi. 1993. Determinants of employment externalization: A study of temporary workers and independent contractors. Administrative Science Quarterly 38(2):195-223. 
Dey, Matthew, Susan N Houseman, and Anne E Polivka. 2006. Manufacturers' outsourcing to employment services. Upjohn Institute Working Paper 07-123. Kalamazoo, MI: W.E. Upjohn Institute.

Feinman, Jay M. 1976. "The development of the employment at will rule." The American Journal of Legal History 20(2):118-135.

Gleason, Sandra E. 2006. The shadow workforce. The shadow workforce: Perspectives on contingent work in the United States, Europe, and Japan, edited by Sandra E. Gleason. Kalamazoo, MI: W.E. Upjohn Institute.

Gramm, Cynthia L., and John F Schnell. 2001. The use of flexible staffing arrangements in core production jobs. Industrial and Labor Relations Review 54(2):245-258.

von Hippel, Courtney et al. 2006. Operationalizing the shadow workforce: Toward an understanding of the participants in nonstandard employment relationships. The shadow workforce: Perspectives on contingent work in the United States, Europe, and Japan, edited by Sandra E. Gleason. Kalamazoo, MI: W.E. Upjohn Institute.

Hipple, Steven. 2001. Contingent work in the late-1990s. Monthly Labor Review (March):3-27.

Houseman, Susan N. 2001. Why employers use flexible staffing arrangements: Evidence from an establishment survey. Industrial and Labor Relations Review 55(1):149-170.

Houseman, Susan N, Arne L. Kalleberg, and George A Erickcek. 2003. The role of temporary agency employment in tight labour markets. Industrial and Labor Relations Review 57(1):105-127.

Kalleberg, Arne L., Jeremy Reynolds, and Peter V. Marsden. 2003. Externalizing employment: Flexible staffing arrangements in US organizations." Social Science Research 32(4):525552.

Kalleberg, Arne L. 2000. Nonstandard employment relations: Part-time, temporary and contract work. Annual Review of Sociology 26(1):341-365.

Kalleberg, Arne L., David Knoke, and Peter V. Marsden. 1995. Interorganizational networks and the changing employment contract. Connections 18(2):32-49.

Kalleberg, Arne L., Peter V. Marsden, Howard E. Aldrich, and James W. Cassell. 1990. Comparing organizational sampling frames. Administrative Science Quarterly 35(4):658688.

Kilcoyne, Patrick. 2005. Occupations in the temporary help services industry. Occupational Employment and Wages. Washington, D.C.: US Department of Labor.

Lautsch, Brenda A. 2003. The influence of regular work systems on compensation for contingent workers. Industrial Relations 42(4):565-588.

Lautsch, Brenda A. 2002. Uncovering and explaining variance in the features and outcomes of contingent work. Industrial \& Labor Relations Review 56(1):23-43.

Lombardi, Britton, and Yukako Ono. 2008. Professional employer organizations: What are they, who uses them, and why should we care? Economic Perspectives 32(4):2-14.

Luo, Tian, Amar Mann, and Richard Holden. 2010. The expanding role of temporary help services from 1990 to 2008. Monthly Labor Review 3-16. 
Mach, Traci L., and John A. Holmes. 2008. The use of alternative employment arrangements by small businesses: Evidence from the 2003 Survey of Small Business Finances.

Manpower. 2009. Manpower employment outlook survey.

Manyika, James et al. 2011. An economy that works: Job creation and America's future.

Masters, John K., and Grant Miles. 2002. Predicting the use of external labor arrangements: A test of the transaction costs perspective. Academy of Management Journal 45(2):431-442.

Mayer, Kyle J, and Jack A. Nickerson. 2005. Antecedents and performance implications of contracting for knowledge workers: Evidence from information technology services. Organization Science 16(3):225-242.

McLaughlin, Diane K., and Alisha J. Coleman-Jensen. 2008. Nonstandard employment in the nonmetropolitan United States. Rural Sociology 73(4):631-659.

Miles, Thomas J. 2000. Common law exceptions to employment at will and U.S. labor markets. Journal of Law, Economics, and Organization 16(1):74-101.

Mitlacher, Lars W. 2007. The role of temporary agency work in different industrial relations systems - A comparison between Germany and the USA. British Journal of Industrial Relations 45(3):581-606.

Muhl, Charles J. 2002. What is an employee? The answer depends on the Federal law. Monthly Labor Review (January):3-11.

Peck, Jamie, and Nikolas Theodore. 2007. Flexible recession: The temporary staffing industry and mediated work in the United States. Cambridge Journal of Economics 31(2):171-192.

Peck, Jamie, Nikolas Theodore, and Kevin Ward. 2005. Constructing markets for temporary labour: Employment liberalization and the internationalization of the staffing industry. Global Networks 5(1):3-26.

Peck, Jamie, and Nikolas Theodore. 1998. The business of contingent work: Growth and restructuring in Chicago's temporary employment industry. Work, Employment \& Society 12(4):655-674.

Polivka, Anne E. 1996. Contingent and alternative work arrangements, defined. Monthly Labor Review 3-9.

Schreft, Stacey L., and Aarti Singh. 2003. A closer look at jobless recoveries. Federal Reserve of Kansas City Economic Review (Second Quarter):45-72.

Smith, Vicki. 1997. New forms of work organization. Annual Review of Sociology 23(1):315339.

Smith, Vicki. 2001. Teamwork vs. tempwork: Managers and the dualisms of workplace restructuring. Working in restructured workplaces: New directions for the sociology of work, edited by Daniel Cornfield, Karen Campbell, and Holly McCammon. Thousand Oaks, CA: Sage Publications.

Smith, Vicki, and Esther B. Neuwirth. 2008. The good temp. Ithaca, NY: ILR Press. 
Stone, K. 2006. Legal protections for atypical employees: Employment law for workers without workplaces and employees with employers. Berkeley Journal of Employment and Labor Law 27(2):251-286.

Theodore, Nik, and Jamie Peck. 2002. The temporary staffing industry: Growth imperatives and limits to contingency. Economic Geography 78(4):463-493. 